\title{
Tanulási és nyelvtanulási stratégiák használata az általános iskola végén és a középiskola elején
}

A nyelvtanulási stratégiák kutatása több évtizedes múltra

tekint vissza. Míg kezdetben a sikeres nyelvtanuláshoz és nyelvtanulókhoz kötódố stratégiák beazonositása volt a cél, addig az utóbbi két évtizedben egyre meghatározóbb lett a stratégiák

pontosabb beazonosítása, a nyelvtanulással összefüggó

háttértényezók kapcsolatának vizsgálata. A tanulmány célja a nyelvtanulási stratégiák és a tanulási stratégiák használatának vizsgálata és kapcsolatának feltárása az általános iskola végén és a középiskola elején.

A nyelvtanulási stratégiák használatának vizsgálata a 70-es években került intenzívebben a figyelem középpontjába, amikor is a sikeres és sikertelen nyelvtanuló jellemzőinek meghatározásával kezdtek el foglalkozni. Mérföldkő volt ebben a munkában Rubin (1975) kutatása, aki a „What the good language learner can teach us” címmel publikálta tanulmányát a témában. Azoknak a nyelvtanulási stratégiáknak a beazonosítását túzte ki célul, amelyeket a sikeres nyelvtanulók használnak, és amelyeket a kevésbé hatékony nyelvtanulókkal is meg kellene ismertetni, hogy sikeres nyelvtanulókká váljanak. Később, a 80-as és 90-es években a nyelvtanulási stratégiák definíciójának kidolgozása, a stratégiák pontosabb beazonosítása, jellemzőinek meghatározása és taxonómiába foglalása került a figyelem középpontjába (Oxford és Burry-Stock, 1995). Ezenkívül a 90-es években egyre intenzívebb kutatás indult el a nyelvtanulás sikerét meghatározó háttértényezők bevonásával, az életkor, a nemek közötti különbségek, a motiváció és az attitüdök hatásának elemzésével. A 2000-es évektől kezdve a vizsgálatok még intenzívebbé váltak, a nyelvtanulási stratégiák kapcsolatának elemzésére, a kognitív és affektív faktorok feltárására került a hangsúly (Kormos és Csizér, 2008, Zhang, Gu és $H u, 2008)$. Az utóbbi másfél évtizedben olyan újabb kutatási terület is kapcsolódott a nyelvtanulási stratégiákhoz, mint a metakogníció vagy az önszabályozott tanulás (Nikolov, 2003). A nyelvtanulási stratégia vizsgálatának egyik leggyakoribb eszköze a Nyelvtanulási stratégia kérdőív (Strategy Inventory for Language Learning, SILL), melynek használata számos kutatáshoz kötődött hazánkban is (lásd pl. Bíró, 2011, Csizér, Piniel és Kontráné, 2015, Napravszky, Tánczos és Mónos, 2009, Nikolov, 2003).

A tanulási stratégiák tanulmányozása több kutatási terület részét képezi. Ilyen például a tanulási szokások vizsgálata (Artelt, Baumert, Julius-McElvany és Peschar, 2003, B. Németh és Habók, 2006, B. Németh, Habók és Csapó 2016, Habók, 2015), az önszabályozott tanulás (D. Molnár, 2013, 2014), a metakogníció területe (Csíkos, 2006, 2007), vagy a szótanulási stratégiák (Thékes, 2015). A tanulási stratégiákra akkor irányult még 
nagyobb figyelem, amikor a PISA 2000-es vizsgálatban helyet kapott, és a tanulók tudásszintjének értelmezéséhez használták. A stratégiák közül a kidolgozó, a memorizáló és a kontrollstratégiákat vonták be a mérésbe.

A tanulmány célja a nyelvtanulási stratégiák definiálási lehetőségeinek bemutatása, majd a csoportosítási lehetőségek ismertetése. Ezt követően kerül sor hazai vizsgálat eredményeinek bemutatására, melyben 7-10. évfolyamos tanulók vettek részt. A nyelvtanulási stratégiák használata mellett vizsgáltuk a tanulási stratégiák használatát is. Arra kerestünk választ, hogy a nyelvtanulási stratégiák és tanulási stratégiák alkalmazása között milyen összefüggések tárhatók fel.

\section{A nyelvtanulási stratégiák meghatározása}

A nyelvtanulási stratégiák fogalmának meghatározása változóan alakul, nincs egy általánosan elfogadott definíció, inkább különböző szempontok szerinti megközelítések találhatóak. Nikolov (2003) megállapításával egyetérthetünk, miszerint egyes kutatók az információfeldolgozásra helyezik a hangsúlyt, és a mentális folyamatokhoz kötik, míg más szakértők a viselkedés, a tevékenységek elemzése alapján közelítik meg a stratégiahasználatot. Vannak olyan szakemberek, akik ezek kombinációját emelik ki.

Bialystock $(1978,71)$ a nyelvtanulási stratégiákat olyan eszközöknek tekinti, melyek az információk feldolgozására vonatkoznak. O’Malley és Chamot $(1990,1)$ szintén az információfeldolgozás, az emlékezetben való rögzítés és a megértés fontosságát hangsúlyozza, mely egyfajta viselkedésen keresztül nyilvánul meg. Cohen (2011) a stratégiákat szintén az információfeldolgozás és a tevékenységek felől közelíti meg. Kiemeli, hogy a tananyag beazonosítása, rendszerezése, emlékezetben történő rögzítése lényeges, de a különböző szituációkban történő alkalmazása teszi lehetővé a gyakorlást. Weinstein és Mayer $(1983,1)$ a viselkedés és gondolatok szerepére hívja fel a figyelmet, melyek a megismerési folyamatokat befolyásolják a sikeres nyelvtanulás érdekében. Chamot $(2004,14)$ a tudatos gondolkodásra és tevékenységekre helyezi a hangsúlyt, melyeket a tanuló egy kitüzött tanulási cél megvalósítása érdekében alkalmaz Oxford, (1990a) olyan tevékenységekként írja le a stratégiákat, melyek a tanulási folyamatot megkönnyítik, és biztosítják azt, hogy a tanuló az előző tapasztalatok alapján új helyzetekben is tudja alkalmazni az előzőkben megszerzett tudást. Arra is felhívja a figyelmet, hogy fontos az, hogy a tanuló irányítani tudja saját tanulási folyamatát, és ebben segít a nyelvtanulási stratégiák használata.

Cohen (2011) megállapította, a nyelvtanulási stratégiákkal kapcsolatban egyetértés van abban, hogy kimutatható a nyelvtanulási stratégiák teljesítménynövelő hatása, azonban az nem mondható el, hogy minden kutató egyetért azzal, hogy a stratégiák gyorsabbá és élvezetesebbé teszik a nyelvtanulást. Platsidou és Sipitanou (2015), valamint Wu (2008) azonban felhívja arra a figyelmet, hogy a nyelvtanuláshoz szükség van stratégiák használatára, mivel kutatási eredmények arról számolnak be, hogy a sikeres nyelvtanuló gyakrabban használja stratégiáit.

\section{A nyelvtanulási stratégiák csoportosítása}

A nyelvtanulási stratégiák csoportosítása széles körü. A fő szempontokat a csoportosítások kialakításánál az képezte, hogy a nyelvtanuló az egyes feladatok megoldásához, az ismeretek elsajátításához vagy a felidézéséhez milyen stratégiákat részesít előnyben. Rubin (1981, Hsiao és Oxford, 2002) és Oxford (1990b) a nyelvtanulási stratégiákat két csoportra osztotta. Az egyik a direkt stratégiák csoportja, a másik az indirekt stratégiá- 
ké. Míg a direkt stratégiák a tanulási folyamatra közvetlenül hatnak, addig az indirekt stratégiák közvetetten. Rubin hat olyan kategóriát sorolt fel, melyek a direkt stratégiahasználathoz köthetők: (1) pontosítás és ellenőrzés, (2) felülvizsgálat, (3) memorizálás, (4) kitalálás és induktív következtetés, (5) deduktív gondolkodás és (6) gyakorlás. Az indirekt stratégiák a gyakorlati lehetőségek megteremtésére és a nyelvtanulás során használt különböző fogások alkalmazására vonatkoznak (Hsiao és Oxford, 2002), úgymint a tanulás tervezése, a célok megfogalmazása, a tanulás monitorozása, ellenőrzése, a jutalmazó mechanizmusok beépítése a tanulási folyamatba, és a társas kommunikációs helyzetekhez kötődő viselkedés. Ehhez a csoportosításhoz kapcsolódva Oxford (1990) a direkt stratégiákhoz sorolta a memóriastratégiákat, melyek a memorizáláshoz kapcsolódnak, a kognitív stratégiákat, melyek a kitalálás, induktív következtetés és a gyakorlás kategóriához köthetőek, valamint a kompenzáló stratégiákat, melyeknek a nyelvtanulás során alkalmazott különböző fogások során van szerepük. Az indirekt stratégiák a szociális stratégiák, melyek a pontosítás és az ellenőrzés területéhez köthetőek, valamint a gyakorlati lehetőségek megkeresésében van szerepük. A metakognitív stratégiák a monitorozáson, felülvizsgálaton keresztül jelennek meg.

O’Malley és Chamot (1990) három kategóriát különböztetett meg, a kognitív, metakognitív és a szociális-affektív stratégiákat. A kognitív stratégiák csoportja emlékeztet Oxford memória- és kognitívstratégia-értelmezésére. Mivel a kognitív stratégiákhoz olyan tevékenységeket köt, mint például a jegyzetelés, kulcsszavak keresése, fordítás vagy az ismétlés, míg a memóriastratégiákhoz sorolja az elképzelést, kidolgozást vagy a csoportosítást. A felülvizsgálat tevékenységén keresztül azonban itt a kompenzáló stratégiák is szerepet kapnak. A metakognitív stratégiák során a figyelem, az önellenőrzés és az értékelés kerül a középpontba, az irányított figyelem, a szelektív figyelem, a tervezés, az önmonitorozás és önértékelés megjelenésén keresztül. A szociális-affektív stratégiák a kooperáción, a felmerülő kérdések tisztázásán keresztül jelennek meg.

O’Malley és Chamot (1990) csoportosításában ugyan még nem jelent meg a szociális és affektív kategóriák szétválasztása, azonban Oxfordnál igen. A szétválasztás indoklása az, hogy így részletesebb képet lehet adni a nyelvtanulóról.

Dörnyei és Skehan (2003) véleménye szerint Oxford (1990), O’Malley és Chamot (1990) kategóriáit alapul véve négy fó csoportot lehet alkotni. Ezek a kognitív, metakognitív, szociális és affektív stratégiák. A kompenzáló stratégiák kikerültek a csoportosításból, a memorizáló stratégiák a kognitív stratégiák részévé váltak, ahogy O’Malley és Chamot (1990) is írta, valamint a szocioaffektív stratégiák külön csoportba kerültek. Dörnyei és Skehan (2003) nyomán megállapítható, hogy a kognitív stratégiáknak az információkkal való manipulációban és transzformálásban van szerepük, míg a metakognitív stratégiák a magasabb rendü stratégiákat foglalják magukban, ahogyan a korábbi felosztásokban is. A szociális stratégiák a kommunikációra és annak gyakorlására vonatkoznak. Az affektív stratégiák pedig az érzelmi feltételeket teremtik meg a nyelvtanuláshoz.

Meg kell azonban jegyezni, hogy vannak kritikák a stratégiák beazonosítása és kapcsolatuk meghatározásakor (Nikolov, 2003). Oxford (1990) is említi azt, hogy az általa beazonosított stratégiáknál több stratégia van, azonban a stratégiák teljes körü beazonosítása, hierarchizálása még várat magára. Dörnyei és Skehan (2003) rávilágított arra, hogy a memorizáló stratégiák kiemelése nem szükséges, besorolhatók a kognitív stratégiákhoz. Hisiao és Oxford (2002) azonban azzal indokolta a szétválasztást, hogy a memóriastratégiának speciális funkciója van. Összefügg ugyan a két stratégia, de a memóriastratégiák olyan technikákat foglalnak magukban, melyek segítségével az információk a hosszú távú memóriába kerülhetnek. Annak ellenére, hogy itt nem egy mély feldolgozásról van szó. Az is felmerült a kritikák során, hogy a stratégáik közül a kompenzáló stratégia inkább a nyelvhasználatra és nem a nyelvtanulásra vonatkozik. 


\section{A nyelvtanulási stratégiák használata}

A nyelvtanulási stratégiák használatát több tényező befolyásolhatja. Meghatározó lehet a nyelvtanulás szintje, a tanuló életkora, kulturális háttere, a tanítás során alkalmazott módszerek és stratégiák. Nagyszámú kutatás alapját képezte az Oxford (1990) által kidolgozott nyelvtanulási stratégiák kérdöív, a Strategy Inventory for Language Learning (SILL), melynek segítségével széles körü áttekintést nyújtottak az általános iskolától a felsőoktatásig a stratégiahasználatról (lásd pl. magyar mintán Bíró, 2011, Doró és Habók, 2013, Habók és Magyar, 2016, Magyar és Habók, 2016, Napravszky, Tánczos és Mónos, 2009, lásd nemzetközi mintán a következő részben ismertetett eredményeket). A következőkben rövid áttekintést adunk arról, hogy mely stratégiák használata a leginkább preferált a kérdőív területei közül. Azt azonban meg kell jegyezni, hogy egy külön tanulmányt lehetne szentelni a teljes körü áttekintésnek.

Platsidou és Sipitanou (2015) 4-9. évfolyamos tanulók stratégiahasználatát vizsgálta. Kutatásukban azt találták, hogy a stratégiahasználat csökken az életkor elörehaladtával, kivéve a kompenzáló stratégiákat. A legmagasabb volt a metakognitív stratégiákat használó tanulók aránya. Magno (2010) 8-12. évfolyamos tanulókkal folytatott vizsgálatában szintén a kompenzáló stratégiák magas alkalmazását találta, és jelentős hatását az angol nyelvtudásra. Al-Qahtani (2013) kutatásában a kognitív stratégiák leggyakoribb használatát tárta fel, de a metakognitív, valamint a szociális stratégiák használata is magas volt. Zhang, Liu, Zhao és Xie (2011) eredményei azt mutatták, hogy a hallgatók leggyakrabban a kompenzáló stratégiákat alkalmazzák, melyet az affektív, metakognitív és szociális stratégiahasználat követ. Chu, Lin, Chen, Tsai és Wang (2015) is arról számolt be, hogy a kompenzáló stratégiák használata a leggyakoribb, melyet a metakognitív stratégiák követnek, majd a kognitív. Radwan (2011) egyetemistákkal végzett kutatása is azt fedte fel, hogy a metakognitív stratégiák alkalmazása volt a leggyakoribb. Azt is megállapította Radwan, hogy azok a tanulók, akik stratégiáikat gyakrabban használják, jobb teljesítményt nyújtanak idegen nyelvből. Magogwe és Oliver (2007) alap-, közép- és felsőfokú oktatásban tanulókat vont be kutatásába. Mindhárom szinten a metakognitív, a szociális és a kognitív stratégiák alkalmazása volt a leggyakoribb. Khalil (2005) eredményei is arra utalnak, hogy a stratégiahasználat inkább az egyetemistákra jellemző, mint a középiskolásokra. A hat terület közül öt esetben, az affektív stratégiák kivételével, számoltak be az egyetemisták gyakoribb stratégiahasználatról. Összességében a kiválasztott minta azonban leginkább a metakognitív és szociális stratégiákat alkalmazta. A stratégiahasználat gyakoriságát azzal indokolták, hogy az egyetemistáknak több lehetőségük van használni a nyelvet, többet kommunikálnak, valamint hosszabb ideje tanulnak idegen nyelvet. Khalil (2005) ezért az osztálytermi gyakorlási lehetőségek biztosítására hívja fel a figyelmet, mely a stratégiahasználatot célzottan is tanítja. Hong-Nam és Leavell (2006) vizsgálatában, melyet 55 nemzetközi hallgatóval végzett, akik angol egyetemi kurzusra jártak, szintén a metakognitív és a szociális stratégiák leggyakoribb használatát találta. A magas metakognitív stratégiahasználatot arra vezetik vissza, hogy azok a tanulók vesznek részt angol nyelvü intenzív programokon, akik instrumentális motivációja is magasabb, és a jövőben is céljuk, hogy használják a nyelvet. A saját tanulás tervezése, ellenőrzése is hozzájárul ahhoz, hogy a teljesítményük emelkedjen. Az affektív stratégiák használata ezzel szemben háttérbe szorult. Ennek oka az lehet, hogy a diákok, ha bizonytalanok, inkább nem szólalnak meg, és az ázsiai kultúrában inkább a másik embert hallgatják meg, mint hogy elöször a véleményüket elmondják. A nyelvtanuláshoz kapcsolódó véleményüket, érzelmeiket sem szívesen osztják meg. Nem gondolnak arra, ha a nyelvtanuláshoz kapcsolódó problémáikat megosztanák, akkor a tanulásban is sikeresebbek lennének.

A fentiekből látszik, hogy a stratégiahasználat rendkívül változatos képet mutat. A nyelvtanulási stratégiák között azonban belső összefüggések is megfigyelhetőek 
(Magno, 2010). Felvetődik a kérdés, hogy a stratégiahasználat gyakorisága meghatározza-e a tudásszintet idegen nyelvből. A tudásszint és a stratégiák kapcsolatának vizsgálatával összefüggésben Magogwe és Oliver (2007) felhívta arra a figyelmet, hogy a jobb idegen nyelvi osztályzat magasabb stratégiahasználatot is jelent, azonban a kép ennél néha differenciáltabb. Chen (1990) azt találta, hogy éppen a jobb tanulók kommunikálnak kevesebbet, de ez alatt az idő alatt sokkal hatékonyabban teszik ezt. Összességében azonban az állapítható meg, hogy az alacsony stratégiahasználat inkább a gyengébb tanulókra jellemző. Magno (2010), valamint Platsidou és Sipitanou (2015) vizsgálata is azt erősítette meg, hogy a jobb angol nyelvi jeggyel rendelkező tanulók magasabb stratégiahasználatot mutattak. Wu (2008) szintén rámutatott arra, hogy a jobb teszteredményt elérő egyetemi hallgatók a memóriastratégiák kivételével szignifikánsan többet is használják stratégiáikat. Az angol nyelvtudási szintjüket azonban leginkább a kognitív stratégiahasználat befolyásolta. A stratégiák közül összességében a kompenzáló stratégiákat választották leggyakrabban a hallgatók. Hong-Nam és Leavell (2006) arra is felhívta a figyelmet, hogy a közepes szintü nyelvtanulók többet használták stratégiáikat. Ezt azzal magyarázták, hogy a különböző szinten lévő tanulóknak más-más igényei vannak. A metakognitív stratégiák alkalmazása például közép- és felsőszinten nagyon fontos. A tanárnak segíteni kell a tanulókat abban, hogy képesek legyen az önértékelésre, és önálló tanulóvá váljanak. Abedini, Rahimi és Zare-ee (2011) a nyelvtanulási stratégiák és az önhatékonyság, valamint az attitüd kapcsolatát vizsgálták alapszakos hallgatóknál. Az önhatékonyság a metakognitív stratégiákon kívül mindegyik stratégiával szignifikáns kapcsolatot mutatott. Az attitüdök közül a memória és kognitív stratégiák összefüggését találták. Al-Qahtani (2013) felhívta arra a figyelmet, hogy a metakognitív, kognitív és szociális stratégiák használata összefüggést mutat a nyelvtanulási motivációval. Az tehát a korábbi kutatásból kiderült, hogy a nyelvtanulási stratégiák kapcsolata az affektív faktorokkal és attitüdökkel gyakrabban kutatott terület, arról azonban kevés információnk van, hogy a nyelvtanulási és tanulási stratégiák kapcsolata miként alakul. A következőkben erre is választ keresünk.

\section{Módszerek}

\section{Minta és adatfelvétel}

A mintát általános iskolás 7. és 8. évfolyamos tanulók, valamint 9. és 10. évfolyamos tanulók alkották. Az általános iskolás részminta 208 fós volt mindkét évfolyamon, míg a 9. évfolyamosok mintája 225 tanulóból állt, a 10. évfolyamé 151 tanulóból. Az általános iskolások két, a középiskolások három intézményből kerültek ki. A tanulók tanítási órán töltötték ki a nyelvtanulási stratégiák kérdőívet az eDia rendszerben. A kérdőív kitöltése körülbelül 20 percet vett igénybe. Kitöltötték a tanulók a PISA 2000 vizsgálatban használt tanulási szokások kérdőívet is, melyre szintén 20 perc állt rendelkezésre. A jelen tanulmányban a kérdőívből a tanulási stratégiák területét vizsgáljuk, melynek három területe került a vizsgálatba, a kidolgozó, a memorizáló és a kontrollstratégiák.

\section{Kutatási kérdések}

A kutatási kérdések arra kerestek választ, hogy van-e különbség az általános iskolás és középiskolás tanulók tanulási és nyelvtanulási stratégiahasználata között, és ha van, mely területen találhatóak. A jobb idegen nyelvi osztályzatot elérő tanulókról feltételezhető, hogy sikeresebb stratégiahasználók. Kutatásunkban megvizsgáljuk, hogy a jeles 
...van-e különbség az általános iskolás és középiskolás tanulók tanulási és nyelvtanulási stratégiahasználata között, és ha van,

mely területen találhatóak. A jobb idegen nyelvi osztályzatot eléró tanulókról feltételezhe-

tó, hogy sikeresebb stratégia-

használók. Kutatásunkban megvizsgáljuk, hogy a jeles és jó osztályzatot eléró tanulók gyakrabban használják-e stratégiái-

kat. Végül arra keresünk választ, hogy a nyelvtanulási és tanulási stratégiák között van-e összefüggés, és ez mely területen mutatkozik. és jó osztályzatot elérő tanulók gyakrabban használják-e stratégiáikat. Végül arra keresünk választ, hogy a nyelvtanulási és tanulási stratégiák között van-e összefüggés, és ez mely területen mutatkozik.

\section{Mérőeszközök}

\section{Nyelvtanulási stratégiák kérdőiv}

A Rebecca Oxford (1990) által kidolgozott Strategy Inventory for Language Learning (SILL) elnevezésủ kérdőívben a tanulóknak ötfokú Likert-skálán kellett válaszaikat megadni a hat stratégiatípushoz kapcsolódóan.

A direkt stratégiák közül a memóriastratégiák a memorizáló technikák használatára vonatkoznak. Arra kellett válaszolni a tanulóknak, hogy az új információk memóriában történő rögzítése és elöhívása során milyen technikákkal segítik a rögzítést, például kötik-e az információkat a már meglévő ismeretekhez, használnak-e rímeket, mozgásos cselekvést, szituációba helyezik-e az információkat.

A kognitív stratégiák a szövegfeldolgozásra, valamint az anyanyelvi beszélőkkel való gyakorlásra vonatkoznak. A kognitív stratégiák során is elötérbe kerülnek a tanulási technikák, azonban itt inkább a feldolgozásra kerül a hangsúly.

A kompenzáló stratégiák a nyelvtanulás során felmerülő nehézségek kiküszöbölésében segítenek. Arra kérdeztek rá, hogy a nyelvtanuló, ha nem ért valamit, megpróbálja-e kikövetkeztetni, hogy mit nem ért, és mit jelenthet egy adott szó az adott kontextusban, másik szóval helyettesíti-e, vagy gesztusokat használ, vagy elmutogatja.

Az indirekt stratégiák közül a metakognitív stratégiák alkalmazása abban segíti a nyelvtanulót, hogy megtervezze a tanulását, megfogalmazzon célokat, fejlessze a nyelvtudását, felismerje a hibáit, és ezeket korrigálja annak érdekében, hogy sikeresebb nyelvtanuló legyen. Fontos az is, hogy a tanuló keresse a lehetőséget arra, hogy gyakoroljon, mások nyelvhasználatát megfigyelje.

Az affektív stratégiák a nyelvtanulás során felmerülö érzelmeket és motivációs állapotot foglalják magukban. Ezek a stratégiák ahhoz járulnak hozzá, hogy a nyelvtanuló leküzdje a nyelvtanulás során felmerülő nehézségeket és félelmeit. Az affektív stratégiákat gyakran használó tanuló többet bátorítja és jutalmazza magát.

A szociális stratégiák arra vonatkoznak, hogy a nyelvtanulás során a nyelvtanuló mennyire keresi a kapcsolatot más beszélgetöpartnerrel, és hogyan viselkedik a beszélgetés alatt. Például, ha nem ért valamit, megkéri-e partnerét, hogy ismételje meg az információt, hibák esetén javítsa a beszédét; jellemző-e az rá, hogy segítséget kér. 


\section{Tanulási szokások kérdőiv}

A Tanulási szokások kérdőív a PISA 2000 vizsgálatban szerepelt. A magyar nyelvű változatot B. Németh és Habók (2006) használta először magyar mintán 7. és 11. évfolyamos tanulók körében. A tanulóknak négyfokú Likert-skálán kellett válaszaikat megadni. A 49 állításból álló kérdöív négy területet fog át, a tanulási stratégiák, a motiváció, az énkép, és a tanulási helyzet preferenciájának területét. Kutatásunkban a tanulási stratégiák vizsgálata történt, melyek közül a kidolgozó (négy állítás), memorizáló (négy állítás) stratégiák, valamint a kontrollstratégiák (négy állítás) alkották a tanulási stratégiák részterületeit. A kidolgozó stratégiák az információk közötti kapcsolatok és összefüggések keresésére vonatkoznak. A memorizáló stratégiák az információk megjegyzésének és rögzítésének vizsgálatát helyezik a középpontba. A kontrollstratégiák az önellenőrzésre, a saját hiányosságok feltárására vonatkoznak, melyeket a hatékony tanulás érdekében használhat a tanuló.

\section{Eredmények}

\section{Az általános és középiskolás tanulók nyelvtanulási stratégiahasználata közötti különbségek}

A SILL esetében elmondható, hogy reliabilitását és validitását számtalan vizsgálatban igazolták (lásd pl. Ardasheva és Tretter, 2013; Doró és Habók, 2013). Doró és Habók (2013) vizsgálatában például a Cronbach $\alpha$ értékei 0,78 és 0,91 között mozogtak. A Tanulási szokások kérdőív szintén megbízható mérőeszköznek bizonyult nemzetközi és magyar mintán egyaránt (Artelt, Baumert, Julius-McElvany és Peschar, 2003; B. Németh és Habók, 2006). B. Németh és Habók (2006) kutatásában 0,65 és 0,67 közötti Cronbach $\alpha$ értékeket talált. A következőkben bemutatott SILL kérdőív reliabilitásmutatói is megfelelőek, az általános iskolás részmintán 0,92 és 0,70 között mozognak, míg a középiskolás részmintán 0,90 és 0,67 között.

1. táblázat. A nyelvtanulási stratégiákat vizsgáló kérdőiv reliabilitásmutatói

\begin{tabular}{|l|c|c|}
\hline \multicolumn{1}{|c|}{ stratégiák } & $\begin{array}{c}\text { általános iskolás részminta } \\
\text { Crb } \alpha\end{array}$ & $\begin{array}{c}\text { középiskolás részminta } \\
\text { Crb } \alpha\end{array}$ \\
\hline memória & 0,81 & 0,76 \\
\hline kognitív & 0,89 & 0,86 \\
\hline kompenzáló & 0,70 & 0,67 \\
\hline metakognitív & 0,92 & 0,90 \\
\hline affektív & 0,77 & 0,70 \\
\hline szociális & 0,87 & 0,82 \\
\hline
\end{tabular}

A tanulási stratégiákat vizsgáló PISA-kérdőív szintén megbízhatóan müködött, azonban a reliabililitás értékek valamivel elmaradtak a nyelvtanulási stratégia kérdőív értékei mögött.

2. táblázat. A tanulási stratégiákat vizsgáló kérdőiv reliabilitásmutatói

\begin{tabular}{|l|c|c|}
\hline \multicolumn{1}{|c|}{ stratégiák } & $\begin{array}{c}\text { általános iskolás részminta } \\
\text { Crb } \alpha\end{array}$ & $\begin{array}{c}\text { középiskolás részminta } \\
\text { Crb } \alpha\end{array}$ \\
\hline kidolgozó & 0,63 & 0,61 \\
\hline memorizáló & 0,60 & 0,60 \\
\hline kontroll & 0,71 & 0,66 \\
\hline
\end{tabular}


Elöször az általános iskolás és középiskolás tanulók eredményét vizsgáltuk meg a nyelvtanulási stratégiák és tanulási stratégiák területén (3. táblázat). A tanulók nyelvtanulási stratégia használatának eredményét összehasonlítva megállapítható, hogy az általános iskolás részminta, valamint a középiskolás részminta között találhatóak szignifikáns különbségek, melyek a kognitív, kompenzáló, metakognitív és szociális stratégiák körében mutatkoztak, mindegyik esetben a középiskolás részminta javára.

3. táblázat. Az általános iskolás részminta, valamint a középiskolás részminta nyelvtanulási stratégia használatának eredményei

\begin{tabular}{|c|l|c|c|c|c|c|}
\hline \multicolumn{2}{|c|}{ stratégiák } & \multicolumn{2}{c|}{ általános iskolás részminta } & \multicolumn{2}{c|}{ középiskolás részminta } & különbség \\
\hline \multirow{2}{*}{ típus } & \multicolumn{1}{|c|}{ terület } & átlag (\%p) & szórás & átlag (\%p) & szórás & $p<$ \\
\hline \multirow{4}{*}{ direkt } & memória & 44 & 19 & 47 & 18 & n. sz. \\
\cline { 2 - 8 } & kognitív & 46 & 20 & 51 & 19 & 0,001 \\
\cline { 2 - 8 } & kompenzáló & 43 & 20 & 48 & 19 & 0,001 \\
\hline \multirow{5}{*}{ indirekt } & metakognitív & 53 & 23 & 59 & 22 & 0,001 \\
\cline { 2 - 8 } & affektív & 42 & 23 & 42 & 21 & n. sz. \\
\cline { 2 - 7 } & szociális & 47 & 25 & 51 & 24 & 0,05 \\
\hline
\end{tabular}

Az általános iskolás részminta eredményeit tekintve a direkt stratégiák esetében a kognitív stratégia legdominánsabb használatát találtuk, mely a memóriastratégiánál $(\mathrm{p}<0,001)$ és a kompenzálóstratégiánál $(\mathrm{p}<0,01)$ is szignifikánsan magasabb volt. A memória és a kompenzálóstratégia között nem volt szignifikáns különbség. Az indirekt stratégiák között minden esetben találhatóak szignifikáns különbségek $(\mathrm{p}<0,001)$, a legmagasabb a metakognitív stratégiák használatának gyakorisága volt.

A középiskolás iskolás részminta eredményei hasonló képet mutattak. A direkt típusú memorizáló és kognitív stratégiák között található szignifikáns különbség, mégpedig a kognitív stratégia javára. A kognitív és kompenzáló stratégia használata szintén mutatott különbséget $(p<0,001)$, ennél a mintánál is a kognitív stratégiák javára $(p<0,01)$. Az indirekt stratégiák használatának gyakorisága szintén eltért a metakognitív stratégiahasználat javára $(\mathrm{p}<0,000)$.

Megvizsgáltuk a tanulók eredményeit is a három tanulási stratégia vonatkozásában. Ebben az esetben a kidolgozó stratégiák alacsonyabb használatát találtuk az általános iskolásoknál (4. táblázat). Érdemes azonban megnézni a memorizáló stratégiák használatát is, ami nagyon magas, az összes eredmény közül a legmagasabb. Mindkét részmintán szignifikánsan kiemelkedtek $(\mathrm{p}<0,000)$.

4. táblázat. Az általános iskolás részminta, valamint a középiskolás részminta tanulási stratégia használatának eredményei

\begin{tabular}{|l|c|c|c|c|c|}
\hline \multicolumn{1}{|c|}{ stratégiák } & \multicolumn{2}{|c|}{ általános iskolás részminta } & \multicolumn{2}{c|}{ középiskolás részminta } & különbség \\
\hline $\begin{array}{c}\text { tíltalános iskolás } \\
\text { részminta átlag } \\
(\% p)\end{array}$ & szórás & $\begin{array}{c}\text { középiskolás } \\
\text { részminta átlag } \\
(\% \text { o })\end{array}$ & szórás & $p<$ \\
\hline kidolgozó & 55 & 20 & 61 & 19 & 0,001 \\
\hline memorizáló & 70 & 19 & 72 & 18 & n. sz. \\
\hline kontroll & 65 & 20 & 66 & 18 & n. sz. \\
\hline
\end{tabular}

Összességében elmondható, hogy a nyelvtanulási stratégiák használata a középiskolásoknál magasabb volt négy területen. Tulajdonítható ez annak, hogy feltételezhetően ez a csoport tudatosabban használja a stratégiákat. Egyes esetekben több nyelvet is tanulnak, 
az általános iskolásoknál 89 tanuló adta meg, hogy másik nyelvet is tanul valamilyen formában, míg a középiskolások esetében 328 fö, vagyis szinte minden tanuló. Szükségük van a jól bevált stratégiák más nyelvre való transzferálására, a kompenzáló stratégiák gyakoribb használatára, a saját tanulás tervezésére. A memorizáló stratégiák használata a tanulási stratégiák közül kiemelkedően magas, míg a memóriastratégiák eredményei nem voltak kiemelkedően magasak. Tény az, hogy a két kérdöív más-más területre összpontosít a memorizálás kapcsán, de mindkét esetben az értelemgazdag memorizálás lenne az elvárt, mely az információk közötti összefüggésekre épít.

\section{A stratégiahasználat közötti különbség általános iskolás részmintán}

Az általános iskolás tanulókat három csoportra osztottuk az idegen nyelvi osztályzatuk alapján. Az elemszám a következő volt: jeles tanulók 110 fö, jó tanulók 118 fö, közepes vagy annál gyengébb tanulók 177 fö. A jelen kutatásban az osztályzatokról gyüjtöttünk adatot, így az elemzéskor az idegen nyelvi osztályzatokkal dolgoztunk. Tudásszintmérö teszt kérdőívhez kapcsolása jövőbeli kutatás része lesz. A jelenlegi mintánk eredményei azt mutatták, hogy a jeles és jó tanulók a memória, a kognitív, a kompenzáló, a metakognitív és a szociális stratégiákat szignifikánsan gyakrabban használják, mint a közepes vagy annál gyengébb tanulók (5. táblázat).

5. táblázat. A jeles, jó, valamint a közepes vagy annál gyengébb osztályzattal rendelkezö általános iskolás részminta nyelvtanulásistratégia-használata közötti különbség

\begin{tabular}{|c|c|c|c|c|c|c|c|}
\hline \multirow{19}{*}{ 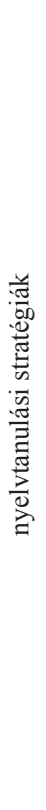 } & stratégia & jegy & átlag $(\% p)$ & szórás & $F$ & $p<$ & szign. különbség \\
\hline & \multirow[t]{3}{*}{ memória } & 5 & 48 & 19 & \multirow{3}{*}{12,84} & \multirow{3}{*}{0,001} & \multirow{3}{*}{$123<4 ; 123<5$} \\
\hline & & 4 & 49 & 17 & & & \\
\hline & & 123 & 39 & 19 & & & \\
\hline & \multirow[t]{3}{*}{ kognitív } & 5 & 56 & 18 & \multirow{3}{*}{30,00} & \multirow{3}{*}{0,001} & \multirow{3}{*}{$123<4 ; 123<5 ; 4<5$} \\
\hline & & 4 & 48 & 18 & & & \\
\hline & & 123 & 39 & 20 & & & \\
\hline & \multirow[t]{3}{*}{ kompenzáló } & 5 & 47 & 16 & \multirow{3}{*}{8,98} & \multirow{3}{*}{0,001} & \multirow{3}{*}{$123<4 ; 123<5$} \\
\hline & & 4 & 47 & 21 & & & \\
\hline & & 123 & 39 & 20 & & & \\
\hline & \multirow[t]{3}{*}{ metakognitív } & 5 & 65 & 20 & \multirow{3}{*}{41,22} & \multirow{3}{*}{0,001} & \multirow{3}{*}{$123<4 ; 123<5 ; 4<5$} \\
\hline & & 4 & 56 & 22 & & & \\
\hline & & 123 & 42 & 22 & & & \\
\hline & \multirow[t]{3}{*}{ affektív } & 5 & 41 & 23 & \multirow{3}{*}{5,36} & \multirow{3}{*}{0,01} & \multirow{3}{*}{$123<4$} \\
\hline & & 4 & 48 & 24 & & & \\
\hline & & 123 & 39 & 22 & & & \\
\hline & \multirow[t]{3}{*}{ szociális } & 5 & 56 & 24 & \multirow{3}{*}{18,15} & \multirow{3}{*}{0,001} & \multirow{3}{*}{$123<4 ; 123<5$} \\
\hline & & 4 & 50 & 26 & & & \\
\hline & & 123 & 39 & 23 & & & \\
\hline
\end{tabular}

Az affektív stratégia esetében állapítottuk meg azt, hogy a négyes tanulók jelentősen gyakrabban használják ezeket a stratégiákat, mint a közepes és annál gyengébb tanulók. A jó és jeles tanulók eredményeit összehasonlítva a jeles tanulók szignifikánsan magasabb stratégiahasználatát találtuk a kognitív és a metakognitív területen. 


\begin{tabular}{|c|c|c|c|c|c|c|c|}
\hline & 6. táblázat. A & $\begin{array}{l}\text { ó, va } \\
\text { olás r }\end{array}$ & $\begin{array}{l}\text { int a közepe } \\
\text { minta tanulc }\end{array}$ & $\begin{array}{l}\text { gy annál } \\
\text { atégia-ho }\end{array}$ & $\begin{array}{l}\text { ébb o. } \\
\text { ata kö }\end{array}$ & $\begin{array}{l}\text { zattal } \\
\text { különb }\end{array}$ & lelkezö általános \\
\hline & stratégia & jegy & átlag $(\% p)$ & szórás & $F$ & $p<$ & szign. különbség \\
\hline \multirow{9}{*}{ 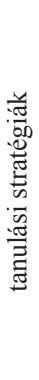 } & \multirow[t]{3}{*}{ kidolgozó } & 5 & 59 & 20 & \multirow[t]{3}{*}{5,33} & \multirow[t]{3}{*}{0,01} & \multirow{3}{*}{$123<4 ; 123<5$} \\
\hline & & 4 & 57 & 19 & & & \\
\hline & & 123 & 51 & 20 & & & \\
\hline & \multirow[t]{3}{*}{ memorizáló } & 5 & 71 & 19 & & \multirow[t]{3}{*}{ n. sz. } & \\
\hline & & 4 & 72 & 16 & & & \\
\hline & & 123 & 68 & 20 & & & \\
\hline & \multirow[t]{3}{*}{ kontroll } & 5 & 68 & 21 & \multirow[t]{3}{*}{3,61} & \multirow[t]{3}{*}{0,05} & \multirow[t]{3}{*}{$123<5$} \\
\hline & & 4 & 66 & 21 & & & \\
\hline & & 123 & 62 & 20 & & & \\
\hline
\end{tabular}

A jó angol osztályzatot elérő tanulók kidolgozó stratégiáikat szignifikánsan gyakrabban használják az eredmények alapján. A kidolgozó és kontrollstratégiáknál a jeles tanulók emelkednek ki a magasabb stratégiahasználattal, a közepes vagy annál gyengébb osztályzatot elérő tanulókhoz viszonyítva (6. táblázat). A memorizáló stratégiák között nincs különbség, minden tanuló egyformán használja ezeket a stratégiákat.

\section{A tanulók stratégiahasználata közötti különbség a középiskolás részmintán}

A stratégiák használatát a középiskolás részminta estében is vizsgáltuk az idegen nyelvi osztályzat alapján. Az elemszám a következően alakult: jeles tanulók 162 fö, jó tanulók 111 fö, közepes vagy annál gyengébb tanulók 102 fö.

Az eredményekből kiderült, hogy a különbségek a nyelvtanulási stratégiák használatában keresendők, a tanulási stratégiák esetében nem mutatkozott különbség (7. és 8 . táblázat).

Az eredmények alapján elmondható, hogy a tanulók között a memória, a kognitív, a metakognitív stratégiák esetében van különbség, mégpedig a jó és jeles tanulók szignifikánsan többet használják ezeket a stratégiákat. A jó és jeles tanulók között is találhatóak különbségek, mégpedig a kognitív, a metakognitív és a szociális stratégiák esetében a jeles tanulók javára, a kompenzáló területen a négyes tanulók javára. A kompenzáló és affektív stratégiák esetében a jeles tanulók szignifikáns magasabb stratégiahasználatát találtuk a közepes vagy annál alacsonyabb osztályzattal rendelkező tanulókhoz képest, míg a szociális startégiák esetében a jó osztályzattal rendelkezők előnye mutatkozott a közepes vagy annál alacsonyabb osztályzattal rendelkező tanulókhoz képest. 
Habók Anita: Tanulási és nyelvtanulási stratégiák használata az általános iskola végén és a középiskola elején

\begin{tabular}{|c|c|c|c|c|c|c|c|}
\hline \multicolumn{8}{|c|}{$\begin{array}{l}\text { 7. táblázat. A jeles, jó, valamint a közepes vagy annál gyengébb osztályzattal rendelkezö } \\
\text { középiskolás részminta nyelvtanulásistratégia-használata közötti különbség }\end{array}$} \\
\hline \multirow{19}{*}{ 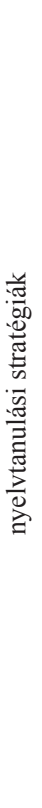 } & stratégia & jegy & átlag (\%) & szórás & $F$ & $p<$ & szign. különbség \\
\hline & memória & 5 & 51 & 17 & \multirow{3}{*}{13,85} & \multirow{3}{*}{0,001} & \multirow{3}{*}{$123<4 ; 123<5$} \\
\hline & & 4 & 47 & 16 & & & \\
\hline & & 123 & 40 & 18 & & & \\
\hline & kognitív & 5 & 59 & 18 & \multirow{3}{*}{39,25} & \multirow{3}{*}{0,001} & \multirow{3}{*}{$123<4 ; 123<5 ; 4<5$} \\
\hline & & 4 & 49 & 15 & & & \\
\hline & & 123 & 40 & 18 & & & \\
\hline & \multirow[t]{3}{*}{ kompenzáló } & 5 & 47 & 18 & \multirow{3}{*}{8,45} & \multirow{3}{*}{0,001} & \multirow{3}{*}{$123<5 ; 5<4$} \\
\hline & & 4 & 53 & 19 & & & \\
\hline & & 123 & 43 & 20 & & & \\
\hline & \multirow[t]{3}{*}{ metakognitív } & 5 & 69 & 19 & \multirow{3}{*}{46,72} & \multirow{3}{*}{0,001} & \multirow{3}{*}{$123<4 ; 123<5 ; 4<5$} \\
\hline & & 4 & 58 & 20 & & & \\
\hline & & 123 & 45 & 20 & & & \\
\hline & \multirow[t]{3}{*}{ affektív } & 5 & 59 & 22 & \multirow{3}{*}{3,30} & \multirow{3}{*}{0,05} & \multirow{3}{*}{$123<5$} \\
\hline & & 4 & 42 & 19 & & & \\
\hline & & 123 & 38 & 20 & & & \\
\hline & \multirow[t]{3}{*}{ szociális } & 5 & 58 & 24 & \multirow{3}{*}{15,49} & \multirow{3}{*}{0,001} & \multirow{3}{*}{$123<4 ; 4<5$} \\
\hline & & 4 & 49 & 23 & & & \\
\hline & & 123 & 42 & 22 & & & \\
\hline
\end{tabular}

8. táblázat. A jeles, jó, valamint a közepes vagy annál gyengébb osztályzattal rendelkezö középiskolás részminta tanulásistratégia-használata közötti különbség

\begin{tabular}{|c|c|c|c|c|c|c|c|}
\hline & stratégia & jegy & átlag (\%) & szórás & $F$ & $p<$ & szign. különbség \\
\hline \multirow{9}{*}{ 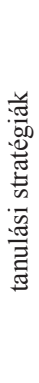 } & \multirow[t]{3}{*}{ kidolgozó } & 5 & 63 & 20 & & \multirow[t]{3}{*}{ n. sz. } & \\
\hline & & 4 & 60 & 18 & & & \\
\hline & & 123 & 60 & 18 & & & \\
\hline & \multirow[t]{3}{*}{ memorizáló } & 5 & 73 & 18 & & \multirow[t]{3}{*}{ n. sz. } & \\
\hline & & 4 & 72 & 19 & & & \\
\hline & & 123 & 71 & 19 & & & \\
\hline & \multirow[t]{3}{*}{ kontroll } & 5 & 67 & 18 & & \multirow[t]{3}{*}{ n. sz. } & \\
\hline & & 4 & 66 & 18 & & & \\
\hline & & 123 & 64 & 18 & & & \\
\hline
\end{tabular}

Míg az általános iskolásoknál volt különbség a jeles és a jó tanulók körében a kidolgozó és kontrollstratégiák között, addig a középiskolásoknál egyik tanulási stratégia esetében sem figyelhető meg szignifikáns különbség.

\section{A stratégiák közötti összefüggések}

Azért, hogy a stratégiák közötti összefüggéseket megvizsgáljuk, áttekintettük a területek közötti korrelációs együtthatókat. Az általános és középiskolás tanulók esetében is megállapítható, hogy erős és közepes szignifikáns korrelációs együtthatók vannak a nyelvtanulási és tanulási stratégiák között, néhány esetben találtunk gyengébb szignifikáns kapcsolatot (9. táblázat). 
9. táblázat. A nyelvtanulási és tanulási stratégiák, valamint az idegen nyelvi osztályzatok korrelációs mátrixa

\begin{tabular}{|c|c|c|c|c|c|c|c|c|c|c|}
\hline & 1. & 2. & 3. & 4. & 5. & 6. & 7. & 8. & 9. & 10. \\
\hline 1. memória & 1 & 0,71 & 0,49 & 0,61 & 0,51 & 0,59 & 0,35 & 0,22 & 0,27 & 0,28 \\
\hline 2. kognitív & 0,72 & 1 & 0,55 & 0,78 & 0,50 & 0,66 & 0,35 & 0,20 & 0,31 & 0,42 \\
\hline 3. kompenzáló & 0,59 & 0,65 & 1 & 0,50 & 0,46 & 0,40 & 0,22 & n. s. & $0,12 * *$ & 0,22 \\
\hline 4. metakognitív & 0,63 & 0,83 & 0,59 & 1 & 0,54 & 0,71 & 0,28 & 0,22 & 0,24 & 0,45 \\
\hline 5. affektív & 0,60 & 0,58 & 0,56 & 0,60 & 1 & 0,58 & 0,22 & $0,16^{*}$ & 0,19 & 0,15 \\
\hline 6. szociális & 0,60 & 0,70 & 0,50 & 0,77 & 0,61 & 1 & 0,25 & 0,20 & 0,23 & 0,28 \\
\hline 7. kidolgozó & 0,47 & 0,39 & 0,35 & 0,35 & 0,37 & 0,35 & 1 & 0,23 & 0,36 & n. $s$. \\
\hline 8. memorizáló & 0,33 & 0,30 & 0,22 & 0,28 & 0,25 & 0,23 & 0,36 & 1 & 0,46 & n. s. \\
\hline 9. kontroll & 0,39 & 0,37 & 0,27 & 0,34 & 0,27 & 0,27 & 0,43 & 0,54 & 1 & n. s. \\
\hline 10. idegen nyelvi jegy & 0,24 & 0,36 & 0,19 & 0,41 & $0,12 * *$ & 0,30 & 0,18 & $0,12 * *$ & $0,14^{*}$ & 1 \\
\hline
\end{tabular}

alsó rész $=$ általános iskolás részminta, felső rész $=$ középiskolás részminta $p<0,001, * p<0,01, * * p<0,05$

A stratégiák és az idegen nyelvi jegyek között is szignifikáns összefüggések mutatkoztak az általános iskolás részmintán, azonban a középiskolás részmintán csak a nyelvtanulási stratégiákkal találhatóak összefüggések.

Megvizsgáltuk a nyelvtanulási és tanulási stratégiák közötti korrelációs együtthatókat a közepes vagy annál alacsonyabb osztályzattal rendelkező tanulók eredményei alapján. Az általános iskolás részmintán minden terület között kimutatható szignifikáns korreláció a közepes vagy annál gyengébb tanulók körében is (10. táblázat).

10. táblázat. A nyelvtanulási és tanulási stratégiák korrelációs mátrixa a közepes vagy annál gyengébb osztályzattal rendelkezö részminták tekintetében

\begin{tabular}{|c|c|c|c|c|c|c|c|c|c|}
\hline & 1. & 2. & 3. & 4. & 5. & 6. & 7. & 8. & 9. \\
\hline 1. memória & 1 & 0,83 & 0,60 & 0,67 & 0,60 & 0,56 & 0,40 & n. s. & n. s. \\
\hline 2. kognitív & 0,77 & 1 & 0,64 & 0,75 & 0,57 & 0,63 & 0,37 & n. s. & n. s. \\
\hline 3. kompenzáló & 0,63 & 0,75 & 1 & 0,62 & 0,49 & 0,51 & $0,25^{*}$ & n. s. & n. s. \\
\hline 4. metakognitív & 0,72 & 0,82 & 0,70 & 1 & 0,60 & 0,68 & $0,26^{*}$ & n. s. & n. s. \\
\hline 5. affektív & 0,69 & 0,69 & 0,63 & 0,74 & 1 & 0,61 & $0,24^{*}$ & n. s. & n. s. \\
\hline 6. szociális & 0,72 & 0,72 & 0,64 & 0,77 & 0,70 & 1 & n. s. & n. s. & n. s. \\
\hline 7. kidolgozó & 0,48 & 0,38 & 0,36 & 0,40 & 0,44 & 0,50 & 1 & n. s. & n. s. \\
\hline 8. memorizáló & 0,24 & 0,29 & $0,18^{*}$ & 0,29 & 0,24 & 0,27 & 0,43 & 1 & \\
\hline 9. kontroll & 0,37 & 0,36 & 0,31 & 0,36 & 0,30 & 0,32 & 0,45 & 0,56 & 1 \\
\hline
\end{tabular}

alsó rész $=$ általános iskolás részminta, felsö rész $=$ középiskolás részminta $p<0,001, * p<0,01$

A középiskolás részmintát tekintve fordított a kép. A közepes vagy annál alacsonyabb osztályzatot elérő tanulók esetében kevesebb a kapcsolat a nyelvtanulási és tanulási stratégiák között. A kidolgozó stratégiák összefüggése a szociális stratégiákat kivéve megfigyelhető, azonban a memorizáló és kontrollstratégiák esetében nem volt szignifikáns kapcsolat.

A jeles tanulók esetében a nyelvtanulási stratégiák között erős a belső kapcsolat, viszont a nyelvtanulási és tanulási stratégiák között nem minden esetben. A kidolgozó tanulási stratégiákat tekintve, a szociális és kidolgozó stratégiák között nem találtunk összefüggést, a többi nyelvtanulási stratégia viszont mutatott szignifikáns kapcsolatot. A memorizáló stratégiák esetében csak a memóriastratégia összefüggése mutatkozott a 
memorizáló stratégiákkal. A kontrollstratégiák esetében a kognitív és metakognitív stratégiák nem mutattak összefüggést a kontrollstratégiákkal, viszont a többi esetben találhatóak szignifikáns kapcsolatok.

A középiskolás részmintán az összefüggések azonban kimutathatóak a jeles tanulók esetében. Náluk a memorizáló-kompenzáló, valamint a kontroll-kompenzáló stratégiák között nem található szignifikáns kapcsolat. A többi esetben azonban szignifikánsak az összefüggések.

\section{Összegzés}

Az idegen nyelv tanulása mindenki számára kihívásokat jelent. A nyelvtanulás folyamatára többféle tényező hat. Meghatározó lehet a szociokulturális háttér, a társas közeg, az egyén meggyőződései az adott nyelvvel kapcsolatban. Az utóbbi néhány évtizedben megnőtt az érdeklődés annak kutatása iránt, hogy a nyelvtanulás alatt a tanulók milyen nyelvtanuláshoz köthető stratégiákat használnak, és hogyan valósítják meg a hatékony tanulást (Bíró, 2011, Csizér, Piniel és Kontráné, 2015, Doró és Habók, 2013, Habók és Magyar, 2016, Magyar és Habók, 2016, Nikolov, 2003, Napravszky, Tánczos és Mónos, 2009, Thékes, 2015, Wong és Nuan, 2011). Azok a tanulók, akik a nyelvtanulási stratégiáikat gyakrabban használják, többet is profitálnak a tanítási órákon, jobb eredményt is érnek el, és feltételezhetően az iskolán kívüli nyelvhasználati szituációkban is sikeresebben állnak helyt.

Megvizsgáltuk Oxford (1990) nyelvtanulási stratégiákkal foglalkozó kérdöíve alapján, hogy a magyar tanulók mely nyelvtanulási stratégiákat használják a leggyakrabban a memória, kognitív, kompenzáló, metakognitív, affektív és szociális

Már a PISA 2000 vizsgálat is felhivta a figyelmet a magas memorizáló stratégiahasználatra, azonban ez a terület továbbra is kiemelkedik. Tény, hogy vannak olyan információk idegen nyelvból is, melyeket szó szerint kell megtanulni, és lehet, hogy nem hordoz értelmet a tanuló számára. Például ilyen lehet egy új szó idegen nyelvból. Azonban a memorizáló stratégiák ilyen magas használata nem lenne indokolt a tanulás során. stratégiák közül. A mintánk a metakognitív stratégiák használatát részesítette leginkább előnyben, mely stratégiapreferencia más kutatásban is megfigyelhető volt, mint ahogy az affektív stratégiák használata alacsony szintje is (Hong-Nam és Leavell, 2006, Napravszky, Tánczos és Mónos, 2009). Az általános és középiskolai részmintát tekintve, a memória és az affektív terület kivételével mindenütt találtunk különbséget a középiskolás részminta javára.

A tanulási stratégiák esetében a kidolgozó stratégiák gyakoribb használatát találtuk a középiskolás részmintánál. A memorizáló stratégiák magas eredménye szintén egybecseng más kutatás eredményével (Artelt és mtsai, 2003, B. Németh és Habók, 2006). Eredményeink figyelemfelkeltőek. Már a PISA 2000 vizsgálat is felhívta a figyelmet a magas memorizáló stratégiahasználatra, azonban ez a terület továbbra is kiemelkedik. Tény, hogy vannak olyan információk idegen nyelvből is, melyeket szó szerint kell megtanulni, és lehet, hogy nem hordoz értelmet a tanuló számára. Például ilyen lehet egy új szó idegen nyelvből. Azonban a memorizáló stratégiák ilyen magas használata nem lenne indokolt a tanulás során. Ha a memóriastratégiák eredményeit megnézzük, akkor nem találjuk kiemelkedőnek, pedig ez a stratégia is az információfeldolgozást állítja a 
középpontba. Valószínűleg itt nem tudatos az a fajta memorizálás, melyet egy-egy szöveg megtanulásánál alkalmaznak.

Eredményeink megerősítették más kutatásokhoz hasonlóan (Wu, 2008), hogy a nyelvtanulásban elért osztályzatok, a nyelvtanulási és tanulási stratégiák között vannak összefüggések. A középiskolásoknál azonban már nem mutatkozott összefüggés az idegen nyelvi jegy és a tanulási stratégiák között. Magyarázható ez talán azzal, hogy a nyelvtanulás során használt stratégiák elkülönülnek más stratégiáktól, és inkább területspecifikusak, nem általánosíthatók. Az idegen nyelvi osztályzatok alapján kapott összefüggések azt mutatták, hogy általános iskolában a gyengébb tanulók stratégiahasználata között több összefüggés fedezhető fel, azonban a középiskolás részminta stratégiahasználata nincs kapcsolatban a memorizáló és kontrollstratégiákkal. Az eredményeket áttekintve azonban megállapítható, hogy van a stratégiák között összefüggés, a tanulási és nyelvtanulási stratégiák tanítása nem választható szét.

Eredményeink más kutatásokhoz hasonlóan (Khalil, 2005) ráirányították a figyelmet arra, hogy az osztálytermi oktatásban, a tananyagtervezésben és a tanárok által használt tanítási módszertanban egyaránt van szerepe a stratégiahasználatnak. Az, hogy a tanuló milyen sikeres a nyelvtanulásban, és hogy mennyire ismeri a stratégiákat, meghatározza előmenetelét. Az idegen nyelv nemcsak érettségi tantárgy, de a diploma kézhezvételének is feltétele. Az azonban, hogy ki mikorra jut el egy közép- vagy felsőfokú nyelvvizsgáig, különböző ideig tart. Már a nyelvtanulás kezdő szakaszában érdemes a tanulóknak stratégiákat bemutatni és monitorozni a tanulási stratégiák használatát. Ehhez megfelelö módszertani eszköztár kidolgozása szükséges.

\section{Irodalomjegyzék}

Abedini, A., Rahimi, A. és Zare-ee, A. (2011): Relationship between Iranian EFL Learners' Beliefs about Language Learning, their Language Learning Strategy Use and their Language Proficiency. ProcediaSocial and Behavioral Sciences, 28, 1029-1033. DOI: $10.1016 /$ j.sbspro.2011.11.188

Al-Qahtani (2013): Relationship between English Language, Learning Strategies, Attitudes, Motivation, and Students' Academic Achievement. Education in Medicine Journal, 5. 3. sz. 19-29. DOI: 10.5959/ eimj.v5i3.124

Ardasheva, Y. és Tretter, T. R. (2013): Strategy Inventory for Language Learning-ELL Student Form: Testing for Factorial Validity. The Modern Language Journal, 97. 2. sz. 474-489. DOI: 10.1111/j.1540-4781.2013.12011.x

Artelt, C., Baumert, J. Julius-McElvany, N. és Peschar, J. (2003): Learners for Life Student Approaches to Learning. Results from PISA 2000. Organisation for Economic Co-Operation and Development. DOI: 10.1787/9789264103917-en

B. Németh Mária és Habók Anita (2006): A 13 és 17 éves tanulók viszonya a tanuláshoz. Magyar Pedagógia, 106. 2. sz. 83-105.

B. Németh Mária, Habók Anita és Csapó Benő (2016): A motivációk és az énkép hatása az olvasási és a matematikai teljesítményre. In: Molnár Gyöngyvér, Bús Enikő (szerk.): PÉK 2016. XIV. Pedagógiai
Értékelési Konferencia $=$ CEA 2016. 14 TH Conference on Educational Assessment. SZTE BTK Neveléstudományi Doktori Iskola, Szeged. 72.

Bíró Enikő (2011): Nyelvtanulási stratégiák három nyelv határán. Iskolakultúra, 8-9. sz. 23-33.

Chamot, A. U. (2004): Issues in Language Learning Strategy Research and Teaching. Electronic Journal of Foreign Language Teaching, 1. 1. sz. 14-26.

Chen, S. Q., 1990. A study of communication strategies in interlanguage production by Chinese EFL learners. Language Learning, 40. 155-187. DOI: 10.1111/j.1467-1770.1990.tb01332.x

Chu, Lin, Chen, Tsai és Wang (2015): The relationships between ambiguity tolerance, learning strategies, and learning Chinese as a second language. System, 49. 1-16. DOI: 10.1016/j.system.2014.10.015

Cohen, A. D. (2011): Strategies in Learning and Using a Second Language. (Longman Applied Linguistics.) Taylor Francis, New York. DOI: 10.4324/9781315833200

Csizér Kata, Piniel Katalin és Kontráné Hegybíró Edit (2015): Hallássérült diákok idegen nyelvvel kapcsolatos egyéni változóinak vizsgálata. Magyar Pedagógia, 115. 1. sz. 3-18.

Csíkos Csaba (2006): Tudatosság és metakogníció viszonya Az ezredforduló interdiszciplináris megközelítései. Iskolakultúra, 16. 12. sz. 69-82. 
Csíkos Csaba (2007): Metakogníció - A tudásra vonatkozó tudás pedagógiája. Müszaki Kiadó, Budapest.

D. Molnár Éva (2013): Tudatos fejlödés: Az önszabályozott tanulás elmélete és gyakorlata. Akadémiai Kiadó, Budapest.

D. Molnár Éva (2014): Az önszabályozott tanulás pedagógiai jelentősége. In: Benedek András és Golnhofer Erzsébet (szerk.): Tanulmányok a neveléstudomány köréből. MTA Pedagógiai Tudományos Bizottság, Budapest. 29-54.

Doró Katalin és Habók Anita (2013): Language learning strategies in elementary school: The effect of age and gender in an EFL context. Journal of Linguistics and Language Teaching, 4. 2. sz. 24-37.

Dörnyei, Z. és Skehan, P. (2003): Individual differences in second language learning. In: Doughty, C. J. és Long, M. H. (szerk.): The handbook of second language acquisition. Blackwell, Oxford. 589-630.

Habók, Anita (2015): Learning to learn in Years 1 and 2 of Hungarian primary schools, Education 3-13: International Journal of Primary, Elementary and Early Years Education, 43. 2. sz. 153-163. DOI: 10.1080/03004279.2013.783875

Habók Anita és Magyar Andrea (2016): Exploring gender and grade differences in language learning strategy use among secondary school children. $8^{\text {th }}$ Biennial Conference of EARLI SIG1: Assessment and evaluation. Building bridges between assessment and evaluation. Munich, 24-26. August, 2016.

Habók Anita és Doró Katalin (2015): The use of learning strategies for English as a second language. In: Gómez Chova, L., López Martínez, A. és Candel Torres, I. (szerk.): EDULEARN15 Proceedings: 7th International Conference on Education and New Learning Technologies. International Academy of Technology, Education and Development (IATED), Valencia. 6746-6753.

Hong-Nam, K. és Leavell, A. G. (2006): Language learning strategy use of ESL students in an intensive English learning context. System, 34. 3. sz. 399-415. DOI: $10.1016 /$ j.system.2006.02.002

Hsiao, T.-Y. és Oxford, R. L. (2002): Comparing Theories of Language Learning Strategies: A Confirmatory Factor Analysis. The Modern Language Journal, 86. 368-383. DOI: 10.1111/1540-4781.00155

Khalil, A. (2005): Assessment of Language Learning Strategies Used by Palestinian EFL Learners. Foreign Language Annals, 38. 1. sz. 108-119. DOI: 10.1111/ j.1944-9720.2005.tb02458.x

Kormos, J. és Csizér K. (2008): Age-Related Differences in the Motivation of Learning English as a Foreign Language: Attitudes, Selves, and Motivated Learning Behavior. Language Learning, 58. 2. sz. 327-355. DOI: 10.1111/j.1467-9922.2008.00443.x
Magogwe, J. M. és Oliver, R. (2007): The relationship between language learning strategies, proficiency, age, and self-efficacy beliefs: A study of language learners in Botswana. System, 35. 3. sz. 338-352. DOI: $10.1016 /$ j.system.2007.01.003

Magno, C. (2010): Korean Students` Language Learning Strategies and Years of Studying English as Predictors of Proficiency in English. TESOL Journal, 2. 39-61.

Magyar Andrea és Habók Anita (2016): The effect of foreign language learning strategy preferences on foreign language attitude and proficiency among lower secondary school children. In: Molnár Gyöngyvér és Bús Enikó (szerk.): PÉK 2016 XIV. Pedagógiai Értékelési Konferencia Program - Elöadás-összefoglalók, CEA 2016 14th Conference on Educational Assessment Program - Abstracts. Universtiy of Szeged, Szeged. 112.

Napravszky Noémi, Tánczos Judit és Mónos Katalin (2009): Diszlexiás és nem diszlexiás általános iskolai tanulók nyelvtanulási stílusainak és stratégiáinak összehasonlító vizsgálata. Új Pedagógiai Szemle, 59. 1. sz. 50-71.

Nikolov, Marianne (2003): Hatodikosok stratégiahasználata olvasott szövegek értését és íráskészséget mérö feladatokon angol nyelvből. Magyar Pedagógia, 103. 1. sz. 5-34.

O’Malley, M. és Chamot, A. U. (1990): Learning Strategies in Second Language Acquisition. Cambridge University Press, Cambridge. DOI: 10.1017/ cbo9781139524490

Oxford, R. (1990a): Language learning strategies: What every teacher should know. Newburry House / Harper és Row, New York.

Oxford, R. L. (1990b): Language learning strategies and beyond: A look at strategies in the context of styles. In: Magnan, S. S. (szerk.): Shifting the Instructional Focus to the Learner. Northeast Conference on the Teaching of Foreign Languages, Middlebury. VT. 35-55.

Oxford, R. L. és J. A. Burry-Stock (1995): Assessing the use of language learning strategies worldwide with the ESL/EFL version of the Strategy Inventory for Language Learning (SILL). System, 23. 1. sz. 1-23. DOI: 10.1016/0346-251x(94)00047-a

Radwan, A. A. (2011): Effects of L2 proficiency and gender on choice of language learning strategies by university students majoring in English. The Asian EFL Journal Quarterly, 13. 1. sz. 114-162.

Rubin, J. (1975): What the „good language learner' can teach us. TESOL Quarterly, 9. 1. sz. 41-51. DOI: $10.2307 / 3586011$

Rubin, J. (1981): Study of cognitive processes in second language learning. Applied Linguistics, 11. 2. sz. 117-131. DOI: 10.1093/applin/2.2.117 
Thékes István (2015): An empirical study into Hungarian young learners' English as a foreign language learning strategies. International Journal of Research Studies in Language Learning. DOI: 10.5861/ ijrs1l.2016.1359

Wong, L. L. C. és Nunan, D. (2011): The learning styles and strategies of effective language learners. System: An International Journal of Educational Technology and Applied Linguistics, 39. 2. sz. 144163. DOI: $10.1016 /$ j.system.2011.05.004
Wu, Y.-L. (2008): Language Learning Strategies Used by Students at Different Proficiency Levels. Asian EFL Journal, 10. 4. sz. 75-91.

Zhang, L. J., Gu, P. Y. és Hu, G. (2008): A cognitive perspective on Singaporean primary school pupils' use of reading strategies in learning to read in English. British Journal of Educational Psychology, 78. 2. sz. 245-271. DOI: 10.1348/000709907x218179

Zhang, Liu, Zhao és Xie (2011): English Test-Taking Strategy Use and Students' Test Performance. The Asian EFL Journal Quarterly, 13. 2. sz. 133-168. 